\title{
Helicobacter pylori CagA IgG pozitifliğinin gastrointestinal yakınmalar ve histopatolojik bulgular ile ilişkisi
}

\author{
The relationship between Helicobacter pylori CagA IgG positivity and gastrointestinal complaints \\ and histopathological findings
}

\author{
Sibel BAKIRCI ÜREYEN ${ }^{1}$, Cumali EFE ${ }^{1}$, Narin NASIROĞLU IMGA ${ }^{1}$, Tankut KÖSEOĞLU², Ersan ÖZASLAN², \\ Hasan TUNCA', Engin SENNAROĞLU' \\ Ankara Numune Eğitim ve Araştırma Hastanesi, ' $G e n e l$ Dahiliye Kliniği, ${ }^{2}$ Gastroenteroloji Kliniği, Ankara
}

\begin{abstract}
Giriş ve Amaç: Güçlü immünojen ve sitotoksin olan Helicobacter pylori CagA dış membran proteinine karşı oluşan IgG tipi antikorların tespitine dayanarak yapılan serolojik testlerin, bu mikroorganizmaların neden olduğu patolojilerin tespitinde kullanımı son yıllarda yaygınlaşmaktadır. Bu çalışmada, Helicobacter pylori'ye karşı oluşmuş CagA IgG antikorlarının gastrointestinal yakınmalar, histopatolojik ve demografik veriler ile ilişkisinin değerlendirilmesi amaçlandı. Gereç ve Yöntem: Farklı gastrointestinal yakınmalar ile dahiliye polikliniğine başvurduktan sonra rutin değerlendirmelerinde üre nefes testi ile Helicobacter pylori açısından pozitif olarak tespit edildikten sonra tanı amaçı̈ı özofagogastroduodenoskopik biyopsi yapılan 18 yaş üzeri toplam 74 hasta çalışmamıza dahil edildi. Bu hastalarda CagA proteinine ait özgül IgG antikor varlığını saptamak için Enzyme Linked Immunosorbent Assay yöntemi kullanıldı. Bulgular: Yetmiş dört hastanın 20'si kadın (\%27) ve 54'ü erkekti (\%73). Helicobacter pylori pozitif saptanan hastaların \%62'sinde CagA IgG pozitifliği saptandı. CagA IgG pozitif hasta grubunda en sık saptanan gastrointestinal şikayet karın ağrısı ve en sık histopatolojik bulgu kronik aktif gastrit olarak tespit edildi. Sonuç: Helicobacter pylori enfeksiyonu ile ilişkili patolojilerin erken tanısında daha ucuz, pratik ve invaziv olmayan bu serolojik testlerin kullanımının standardize edilmesi için uzun dönemli ve büyük örneklem büyüklüğüne sahip çalışmaların yapılmasına ihtiyaç vardır.
\end{abstract}

Anahtar kelimeler: Helicobacter pylori, CagA IgG, gastrointestinal şikayetler, histopatoloji, üre-nefes testi
Background and Aims: In recent years, there has been a widespread use of serologic tests based on detection of IgG-type antibodies against Helicobacter pylori CagA outer membrane protein, which is a strong immunogen and cytotoxin, for the identification of pathologies caused by these microorganisms. The aim of this study was to evaluate the relationship between CagA IgG antibodies against Helicobacter pylori and gastrointestinal complaints and histopathological and demographic data. Material and Methods: This study included 74 adult patients who were admitted to the internal medicine outpatient clinic with different gastrointestinal complaints, showed Helicobacter pylori positivity in the urea breath test, and underwent esophagogastroduodenoscopic biopsy because of the diagnosis. The presence of Ig G antibodies against CagA protein was detected by Enzyme Linked Immunosorbent Assay. Results: The 74 patients included 20 (27\%) females and 54 (73\%) males. CagA IgG positivity was detected in $62 \%$ of the Helicobacter pylori-positive patients. The most common gastrointestinal complaint was abdominal pain, and the most common histopathological finding was chronic active gastritis in the CagA IgG-positive patient group. Conclusion: Further long-term studies with a large sample size are needed to standardize the use of these serologic tests, which are inexpensive, practical, and noninvasive, in the early diagnosis of pathologies associated with Helicobacter pylori infection.

Key words: Helicobacter pylori, CagA IgG, gastrointestinal complaints, histopathology, urea breath test

\section{Giriș}

Helicobacter pylori (Hp), gram negatif, mikroaerofilik, spiral şeklinde bir mikroorganizma olarak tanımlanmışıı. Bütün dünyadaki insanların en az \%50'sinin midesinde kolonize olmaktadır (1). Türkiye'de 2013 yılında yapılan bir çalışmada $H p$ prevalansı yaklaşık \%82.5 oranında bulunmuştur (2).

Üzerinde birçok araştırma yapılan bu mikroorganizmanın, akut ve kronik gastrit, kronik atrofik gastrit, intestinal metaplazi, peptik ülser ve mide kanseri patogenezinde rol oynadığı yapılan epidemiyolojik ve klinik çalısmalarla gösterilmiştir (3).

Hp enfeksiyonu tanısında, çok sayıda invaziv ve non-invaziv yöntemler kullanılmaktadır. Non-invaziv testler; üre nefes testi (ÜNT), seroloji, dışkı kültürü, gaita antijen testi, dışkı polimeraz zincir reaksiyonu ve serolojik testlerdir. Invaziv testler ise; endoskopik incelemeler ile yapılabilen histopatolojik değerlendimeler, hızlı üreaz testi, kültür ve moleküler yöntemlerdir (4). Her bir testin kendine göre 
avantajı ve dezavantajı olmasından dolayı birden fazla testin tanı amacıyla kullanılması oldukça yaygındır. Hp tanısında kullanılan non-invaziv testlerden biri olan serolojik testler ile, $H p$ ile temas sonrasında serumda $H p^{\prime}$ ye karşı gelişen immünglobulin $A(\lg A)$, immünglobulin $G(\lg G)$ ve immünglobulin $\mathrm{M}$ (IgM) antikorlarının ölçümü hedeflenir. Antikorlar enfeksiyona karşı koruyucu olmaktan çok tanı değeri taşımaktadır (5). Hp tanısında ilk kullanılan serolojik testlerden biri Enzyme Linked Immunosorbent Assay (ELISA)'dır (4). Bu testlerin duyarlılık ve özgüllüğünü artırmaya yönelik çabalar sonucu sitotoksin ilişkili gen A (CagA) gibi klinik ve patolojik önemi olan spesifik proteinlere karşı antikor cevabını ölçebilen enzim işaretli katı faz immunoassay, pasif hemaglutinin ve Western Blot gibi yeni serolojik yöntemler geliştirilmiştir (6).

CagA 128 kDa molekül ağırlığındadır ve güçlü bir immünojen ve sitotoksin olan CagA dış membran proteinini kodlar. CagA proteini bakteri stoplazması içerisinde membrana yakın bir bölgede lokalizedir ve dış ortamdaki pH'nın düşmesine cevap olarak ribozomlarda üretilir. $\mathrm{Hp}$ suşlarının \%60-80'ninde CagA geninin varlığı gösterilmiştir. CagA genini taşıyan $H p$ suşlarının daha virülan ve daha fazla peptik ülser ve gastrik adenokarsinom ile ilişkili olduğu gösterilmiştir (7). Hp'nin neden olduğu doku hasarını indükleyen faktörlerden biri olan CagA, bazı çalışmalarda onkoprotein olarak da tanımlanmıştır $(8,9)$.

Çalışmamızda, farklı gastrointestinal sistem yakınmaları ile başvuran ve rutin değerlendirmelerinde ÜNT ile Hp pozitif saptanan ve tanı amaçlı özofagogastroduodenoskopik (ÖGD) biyopsi yapılması planlanan hastalarda, Hp'ye karşı oluşmuş CagA ıgG antikorlarının gastrointestinal yakınmalar, histopatoloji ve demografik veriler ile ilişkisini değerlendirmeyi amaçladık.

\section{GEREÇ ve YÖNTEM}

Ankara Numune Eğitim ve Araştırma Hastanesi (ANEAH) dahiliye polikliniklerine 2007 ve 2009 tarihleri arasında gastrointestinal semptomların araştıııması amacıyla başvuran ve ÜNT testi ile Hp pozitif tespit edildikten sonra tanı amacıyla ÖGD'si yapılan 18 yaş üzerinde toplam 74 hasta çalışmamıza dahil edildi. Çalışmamız için etik kurulu onayı bağlı bulunduğumuz kurumdan alındıktan sonra hastalardan çalışmaya katılmadan önce bilgilendirilmiş olur formu alındı.

Çalışmaya katılmadan önceki 3 ay içerisinde anti-sekretuvar, sükralfat veya bizmut içeren bileşik, non-steroid anti-enflamatuvar ilaç tedavisi alanlar; herhangi bir nedenle son 6 ay içerisinde antibiyotik tedavisi alanlar, son 1 yıl içerisinde $H p$ eradikasyon tedavisi alanlar, kronik organ yetmezliği olanlar, mide ameliyatı geçirmiş olanlar ve mide dışı kanseri olan hastalar çalışmaya alınmamıştır.

Hastaların yaş, cinsiyet, sigara ve alkol alışkanlıkları, ekonomik durum (gelir kaynaklarına göre subjektif olarak iyi, orta ve kötü olarak sınıflandırıldı) ve öğrenim düzeyi (ilk-orta okul veya okur yazar olmayan, lise ve üniversite olarak 3 gruba ayrıldı) gibi demografik verileri ve başvuru şikayetleri kaydedildi. Hastaların başvuru sırasındaki gastrointestinal şikayetleri; karın ağrısı, dispepsi ve diğer bulgular (hematemez, kilo kaybı, halsizlik) olarak 3 gruba ayrılarak CagA IgG pozitif ve negatif olan gruplarla ilişkisine bakıldı.

\section{Üre Nefes Testinin Değerlendirilmesi}

Bu test icin hastalar, bir mikroküri $14 \mathrm{C}$ ile işaretli üre tabletini, en az 4 saatlik açlık sonrası $50 \mathrm{ml}$ su ile birlikte içtikten sonra dolaşıma geçen karbondioksit gazının solunum yoluyla atılması için 10 dakika beklenerek hastalardan nefes örneği vermeleri istenildi. Bu amaçla hastalar, özel olarak hazırlanmış nefes kartını üfleyerek şişirdiler. Ekspirasyonun doğru olarak yapıldığına emin olunduktan sonra membranın üzerindeki turuncu rengin sarıya dönmesi pozitiflik kriteri olarak degerlendirildi. ÜNT duyarlılık (\%95) ve özgüllük (\%100) oranı oldukça yüksek bir testtir (10).

\section{Üst Gastrointestinal Sistem Endoskopik İncelemesi}

Endoskopik inceleme ANEAH endoskopi laboratuvarında, fiberoptik endoskoplar kullanılarak yapıldı (Fujinon-System-4400). Endoskopik işlem sırasında histopatolojik örnekleme için her hastadan küçük kurvatur ve büyük kurvatur tarafından 2 adet antrum ve 2 adet korpus biyopsi örnekleri alındı. Hp'nin varlığı histopatolojik olarak değerlendirildi. Tüm antral biyopsi örnekleri histolojik inceleme için \%10 formalin ile fikse edildi. Parafin balmumu ile tespit edilip kesitlere bölündü. Tüm doku bölümleri histolojik inceleme için Hematoksilen-Eosin ve Giemsa ile boyandı. Tüm mide örnekleri aynı patolog tarafından çalışmadaki hastaların klinik bilgilerinden habersiz olarak değerlendirildi. Endoskopik bulgular; kronik gastrit, kronik aktif gastrit, intestinal metaplazi ve adenokarsinom olarak gruplandırıldı. Endoskopik biyopsi örneklerinin patoloji değerlendirilmesi şu şekilde yapıldı; lamina propriyada lenfosit ve plazma hücrelerinde artış gözlendiğinde "kronik gastrit", aynı alanda ve yüzey epitelinde nötrofil infiltrasyonu gözlendiğinde "kronik aktif gastrit" ve mukoza epitelinde intestinal metaplazi gözlenmesi durumunda ise "intestinal metaplazi" olarak yorumlandı. Intestinal displazi bu sınıflandırmanın içinde değerlendirilmedi (11). 


\section{Mikroelisa Kiti (CagA IgG) Değerlendirilmesi}

Endoskopik işlem yapılan günün sabahı hastalardan aç karnına ELISA analizleri için antekübital venden 10 cc venöz kan örnekleri alınarak $-20{ }^{\circ} \mathrm{C}^{\prime}$ de inceleme yapılacak güne kadar saklandı. Hp pozitif olan hastalarda CagA proteinine özgül antikor varlığını saptamak için mikroelisa kiti (CagA IgG) kullanıldı. Çalışmaya başlamadan önce serumlar oda sıcaklığına alınarak erimeleri sağlandı. Sonuçlar "arbitrary units per mililiter" (arb $\mathrm{U} / \mathrm{ml}$ ) cinsinden kantitatif olarak belirtildi. CagA > $\mathrm{arbU} / \mathrm{ml}$ 'in üzerinde olan değerler pozitif, 5 arb U/ml'in altında olan değerlerdeki örnekler ise CagA lgG antikoru negatif kabul edildi. Bu testin bilinen duyarlılığı >\%98 ve özgüllüğü >\%98 olarak tespit edilmiştir $(6,12)$.

\section{İstatistiksel Analiz}

Verilerin analizi SPSS, Windows 11.5 paket programında yapıldı. Sürekli ölçümlü değişkenler ortalama (standart sapma) şeklinde gösterilirken nominal değişkenler olgu sayısı ve (\%) olarak ifade edildi. Gruplar arasında ortalamalar yönünden farkın önemliliği bağımsız grup sayısı iki olduğunda Student's t testi ile bağımsız grup sayısının ikiden fazla olması durumunda "Tek Yönlü Varyans Analizi" ile ortancalar yönünden farkın önemliliği ise bağımsız grup sayısı iki olduğunda "Mann Whitney U testi" ile bağımsız grup sayısının ikiden fazla olması durumunda "Kruskal Wallis testi" ile değerlendirildi. Kruskal Wallis test istatistiği sonucunun önemli bulunması halinde an- lamlı farka neden olan grup/grupları tespit etmek amacıyla parametrik olmayan çoklu karşılaştırma testleri yapıldı. Nominal değişkenler Pearson'un Ki-Kare veya Fisher'in Tam Sonuçlu Olasılık testi ile değerlendirildi. p<0.05 için sonuçlar istatistiksel olarak anlamlı kabul edildi.

\section{BULGULAR}

Patoloji ve ÜNT sonucu pozitif saptanan 74 hastanın 20'si kadın (\%27) ve 54'ü erkekti (\%73). Hastalar Hp CagA IgG negatif veya pozitifliği temel alınarak iki gruba ayrıldı. Endoskopik biyopsi ile Hp pozitif saptanan 38 hastanın $\% 62.5^{\prime}$ inde ( $\left.n=20\right)$ CagA IgG pozitifliği tespit edildi. ÜNT ile $H p$ pozitif saptanan hasta grubunda demografik veriler CagA IgG pozitif ( $n=38$ ) veya negatif $(n=36)$ olmasına göre iki grupta karşılaştırılarak Tablo 1'de özetlendi.

Hastaların yaş, cinsiyet, sigara ve alkol alışkanlıkları, ekonomik durumu, öğrenim düzeyi ile CagA IgG pozitif ve negatif gruplar karşılaştıııldığında istatistiksel olarak anlamlı bir veri saptanmadı.

Gastrointestinal başvuru şikayetleri; karın ağrısı, dispepsi (bulantı, kusma, şişkinlik, yanma) ve diğer bulgular (hematamez, kilo kaybı, halsizlik) olarak 3 gruba ayrılarak karşılaştırmalar yapıldı. Karın ağrısı, CagA IgG pozitif olan grupta istatistiksel olarak anlamlılığa ulaşmamakla beraber dispepsi ve diğer şikayetlere göre daha yüksek sıklıkta tespit edildi (sırasıyla \%65.8, \%26.3, \%7.9; $p=0.172$ ) (Tablo 2).

\section{Tablo 1. CagA negatif ve pozitif olan hastalardaki demografik verilerin karşılaştırılması}

\begin{tabular}{|c|c|c|c|}
\hline & CagA (-) $(n=36)$ & $\operatorname{CagA}(+)(n=38)$ & p değeri \\
\hline Yaş (yıl)* & $46.4(19.5)$ & $51.5(18.9)$ & 0.372 \\
\hline \multicolumn{4}{|l|}{ Cinsiyet } \\
\hline Kadın & $9(\% 25)$ & $9(\% 30)$ & \\
\hline Erkek & $27(\% 75)$ & $21(\% 70)$ & \\
\hline \multicolumn{4}{|l|}{ Alışkanlıklar } \\
\hline Sigara & $11(\% 30.6)$ & $12(\% 40)$ & 0.618 \\
\hline Alkol & $2(\% 5.6)$ & $2(\% 6,7)$ & 0.613 \\
\hline \multicolumn{4}{|l|}{ Ekonomik Durum } \\
\hline lyi & $7(\% 19.4)$ & $3(\% 10)$ & 0.316 \\
\hline Orta & $21(\% 58.3)$ & $19(\% 63.3)$ & \\
\hline Kötü & $8(\% 22,2)$ & $8(\% 26,7)$ & \\
\hline \multicolumn{4}{|l|}{ Öğrenim düzeyi } \\
\hline Illk-orta okul veya okur yazar olmayan & $24(\% 66.7)$ & $26(\% 86.7)$ & 0.243 \\
\hline Lise & $8(\% 22.2)$ & $4(\% 13.3)$ & \\
\hline Üniversite & $4(\% 11.1)$ & - & \\
\hline
\end{tabular}

Tüm veriler ortalama (standart deviasyon)* veya $\mathrm{n}(\%)$ olarak verilmiştir. 
Tablo 2. CagA negatif ve pozitif hastalardaki gastrointestinal yakınmaların dağııımı

\begin{tabular}{lccc}
\hline Yakınmalar* & CagA (-) $(\mathbf{n}=\mathbf{3 6})$ & CagA (+) $(\mathbf{n}=\mathbf{3 8})$ & p değeri \\
\hline Karın ağrısı & $17(\% 47.2)$ & $25(\% 65.8)$ & 0.172 \\
\hline Dispepsi & $17(\% 47.2)$ & $10(\% 26.3)$ & \\
\hline Diğer & $2(\% 5.6)$ & $3(\% 7.9)$ &
\end{tabular}

Tüm veriler $n(\%)$ olarak verildi. *Hematemez, kilo kaybı ve halsizlik şikayetleri ise diğer başlık altında toplanıldı.

Tablo 3. CagA negatif ve pozitif hastalardaki histopatolojik bulguların dağılımı

\begin{tabular}{lccc}
\hline Histopoatolojik Bulgular & CagA $(-)(\mathbf{n = 3 6 )}$ & CagA (+) (n=38) & p değeri \\
\hline Intestinal metaplazi & $2(\% 5.6)$ & $2(\% 5.3)$ & 0.216 \\
\hline Kronik gastrit & $20(\% 55.6)$ & $14(\% 36.8)$ & $17(\% 44.7)$ \\
\hline Kronik aktif gastrit & $13(\% 36.1)$ & $5(\% 13.2)$ & \\
\hline Adenokarsinom & $1(\% 2.8)$ & &
\end{tabular}

Tüm veriler $n$ (\%) olarak verildi.

Histopatolojik bulgular; intestinal metaplazi, kronik gastrit, kronik aktif gastrit ve adenokarsinom olarak 4 gruba ayrllarak CagA IgG pozitif ve negatif olan gruplarla karşılaştırmalar yapıldı. CagA IgG pozitif olan grupta istatistiksel anlamlılığa ulaşmamakla birlikte, kronik aktif gastrit ve kronik gastrit sıklı̆ı diğer bulgulardan daha yüksek sıklıkta gözlendi (sırasıyla \%44.7, \%36.8, \%5.3, \%13.2; $\mathrm{p}=0.216$ ) (Tablo 3).

Gastrointestinal yakınmalar ile histopatolojik bulguların karşılaştırmasında ise istatistiksel anlamlılı̆a ulaşmamakla birlikte tüm patolojik bulgulara en sık eşlik eden semptom karın ağrısı olarak saptandı. Intestinal metaplazisi olanların $\% 75^{\prime} i$, kronik gastriti olanların $\% 58.8^{\prime} i$, kronik aktif gastriti olanların \%50'si, adenokarsinomu olan hastaların $\% 66.7$ 'si karın ağrısı şikayeti ile başvurmuştu $(p=0.652)$.

\section{TARTIŞMA}

Helicobacter pylori ile enfekte olan kişilerde devamlı bir humaral immün yanıt bulunması, tanı için serolojik yöntemlerden yararlanabilmeye olanak sağlamıştır $(5,6)$. Inflamatuvar olaylar tüm midede homojen olarak dağımadığı için, sadece biyopsi sonucu ile tanı koymak hatalı sonuçlara neden olabilmektedir. Hp'nin midede odaklar halinde bulunmasından dolayı bazı uzmanlar, tanı aşamasında serolojik testlerin, biyopsiden daha sağlıklı sonuçlar verebileceğini ileri sürmektedir (13).

Helicobacter pylori ile enfekte bireylerin çoğunun semptomsuz olması ve bu histopatolojik değişikliklerin her bireyde gelişmemesi nedeniyle bakteriye ait virülans faktörleri ve konakçının yanıını etkileyen faktörler önem kazanmışır. Ayrıca; CagA, Hp'nin prekanseröz lezyonlar oluşturmasında önemli bir katkıya sahiptir ve bu lezyonların görülme sıklı̆ını artırmaktadır $(8,9)$. Bu nedenle invaziv olmayan ve daha yaygın kullanılabilecek yöntemlere olan intiyacın zamanla artması nedeniyle serolojik testlere olan ilgi de artmıştır. Çalışmamızda ÜNT ve üst endoskopik biyopsi ile $H p$ tanısı konulan hastalarda CagA IgG pozitiflik oranı \%62.5 oranında tespit edildi ve CagA IgG pozitif hasta grubunda en sık tespit edilen gastrointestinal şikayet karın ağrısı ve en sık tespit edilen histopatolojik bulgu kronik aktif gastrit olarak saptandı. CagA IgG negatif olan grupta kronik gastrit diğer bulgulara göre daha sık gözlenmektedir. Bu bilgiden yola çıkarak, CagA IgG pozitifliği ile aktivite arasında bir ilişkili olabileceği konusunda bir hipotez öne sürülebilir. Daha önceki çalışmalarda da CagA genini taşıyan Hp suşlarının viral yükünün ve doku hasarının daha fazla olduğu belirtilmiş̧tir (7-9).

Helicobacter pylori enfeksiyonunun prevalansı gelişmekte olan ülkelerde \%70-80 olarak gözlenirken, gelişmiş ülkelerde \%20-50 oranında gözlenir (14). Bu ırksal ve çevresel faktörlerin $H p$ enfeksiyon oranlarındaki farklılıklar ile ilişkili olabileceğini düşündürmektedir. Syam ve ark. Hp prevalansı ile cinsler ve yaş grupları arasında bir ilişkinin olmadığını belirtmişlerdir (15). CagA gen pozitifliği ile sigara kullanımı arasındaki ilişkinin araştııılığı bir çalışmada hem virülans faktörleri hem de bakteriyel virülans yükü ile sigara kullanımının sinerjistik bir etkisinin olabileceği bildirilmiştir (16). Yakın zamanlı diğer bir çalışmada ise alkol kullanımı ile $H p$ varlığı arasında negatif bir ilişki olabileceği öne sürülmüştür (17). Eğitim seviyesi ile CagA pozitifliğini birebir literatürde irdeleyen bir çalışma tespit 
edilmedi. Çalışmamızda demografik veriler ile CagA pozitifliği arasında anlamlı bir ilişki bulunmadı.

CagA, Hp suşlarının \%60-70'inde tespit edilebilmekte, ancak pozitiflik oranı coğrafi farklılıklar göstermektedir $(18,19)$. Bizim çalışmamızda da bu oran $\% 62.5$ oranında bulundu.

Helicobacter pylori'nin tanımlandığı dönemden itibaren karın ağrısı ve $H p$ arasındaki ilişkiyi belirleyebilmek için pek çok çalışma yapılmış ve çalışmalarda çelişkili bulgular tespit edilmiştir. Bazı çalışmalarda birliktelikleri sık bulunurken bazılarında bulunmamışırı $(18,20)$.

Helicobacter pylori CagA antikor düzeyi daha yüksek tespit edilen hastaların daha ciddi doku hasarına maruz kaldıkları, artmış duodenal ülser, mide adenokarsinomu ve mide mukoza ilişkili lenfatik doku (MALT) lenfoma riski ile karşı karşıya oldukları yapılan calısmalar ile gösterilmiştir $(19,21,22)$. CagA pozitif suşların negatif olanlara göre daha belirgin mide mukozası enflamasyonu yaptığı ve atrofik gastrite yol açtıkları saptanmıştır (21). Bir çalışmada semptomu olan gastrik kanser ve peptik ülseri olan hastalarda CagA pozitifliği \%73.3 olarak bulunurken, semptomu olup ülser ve kanseri bulunmayan hastalarda bu oran \%40 olarak tespit edilmiştir ( $p=0.004$ ) (18). Çalışmamızda, CagA IgG pozitif olan grupta adeno-karsinom varlığı, CagA IgG negatif olan gruptan daha fazla gözlendi (\%2.8'e karşı \%13.2).

\section{KAYNAKLAR}

1. Eusebi LH, Zagari RM, Bazzoli F. Epidemiology of Helicobacter pylori infection. Helicobacter 2014;19:1-5.

2. Ozaydin N, Turkyilmaz SA, Cali S. Prevalence and risk factors of Helicobacter pylori in Turkey: a nationally-representative, cross-sectional, screening with the 13C-Urea breath test. BMC Public Health 2013;13:1215.

3. McColl KE. Helicobacter pylori infection. N Engl J Med 2010; 362:1597-604.

4. Tonkic A, Tonkic M, Lehours P, Mégraud F. Epidemiology and diagnosis of Helicobacter pylori infec-tion. Helicobacter 2012;(17 Suppl 1):1-8.

5. Braden B. Diagnosis of Helicobacter pylori infection. BMJ 2012;344:e828

6. Yilmaz O, Sen N, Küpelioğlu AA, Simşek I. Detection of H. pylori infection by ELISA and Western blot techniques and evaluation of anti CagA seropositivity in adult Turkish dyspeptic patients. World J Gastroenterol 2006;12:5375-8.

7. Wu H, Nakano T, Daikoku E, et al. Intrabacterial proton-dependent CagA transport system in Helicobacter pylori. J Med Microbiol 2005;54:1117-25.

8. Franco AT, Israel DA, Washington MK, et al. Activation of beta-catenin by carcinogenic Helicobacter pylori. Proc Natl Acad Sci U S A 2005;102:10646-51.

9. Krueger S, Hundertmark T, Kalinski T, et al. Helicobacter pylori encoding the pathogenicity island activates matrix metalloproteinase 1 in gastric epithelial cells via JNK and ERK. J Biol Chem 2006;281:2868-75.
Diğer bir çalışmada CagA IgG pozitif olan olgularda daha fazla kronik aktif gastrit (\%66) olduğu gözlenmiştir (23). Çalışmamızda ise, CagA pozitif olan hastaların $(n=38)$, 17'sinde kronik aktif gastrit, 14'ünde kronik gastrit, 2'sinde intestinal metaplazi, 5'inde ise adenokarsinom gözlendi (Tablo 2). Çalışmamızın bazı kısıtlııkları mevcuttur. Bunlardan biri çalışmaya dahil edilen hasta grubunun yaş, cinsiyet açısından homojen olmamasıdır. Diğer bir kısıtlılığımız da şikayetlerin hastalarca tanımlanmasının subjektif olması ve görece olarak örneklem sayısının küçük olmasıdır.

Hp enfeksiyonunun tanısında aktivitenin ve klinik şiddetin önceden tahmin edilmesinde, endoskopi pahalı, zaman alıcı ve uygulamasında bazı problemler oluşturabilen girişimsel bir yöntemdir. Bu yüzden dispeptik yakınmaları olan hastaların endoskopi öncesi veya tedavi öncesi ilk tarama testi olarak serolojik testlerin kullanımının standardize edilerek uygulanmasının desteklenmesi için daha büyük örneklem büyüklüğüne sahip, prospektif çalışmaların varlığına ihtiyaç vardır.

Sonuç olarak invaziv olmayan serolojik testlerin standardize edilerek kullanımının yaygınlaşması ile toplam endoskopi intiyacı azaltılabilinir ve $\mathrm{Hp}$ enfeksiyonu ile ilişkili hastalıkların tanısı daha ucuz ve pratik bir yöntemle daha erken dönemde konulabilir.
10. Zhou Q, Li L, Ai Y, et al. Diagnostic accuracy of the 14C-urea breath test in Helicobacter pylori in-fections: a meta-analysis. Wien Klin Wochenschr 2017;129:38-45.

11. Dixon MF, Genta RM, Yardley JH, Correa P. Classification and grading of gastritis. The updated Sydney System. International Workshop on the Histopathology of Gastritis, Houston 1994. Am J Surg Pathol 1996;20:1161-81.

12. Fakhre-Yaseri $H$, Baradaran-Moghaddam A, Shekaraby $M$, et al. Evaluating the relationship between serum immunoglobulin $G$ $(\lg G)$ and $A(\lg A)$ anti-CagA antibody and the $<i>\operatorname{cag} A</ i>$ gene in patients with dyspepsia. Iran J Microbiol 2017;9:97-102.

13. Amieva MR, El-Omar EM. Host-bacterial interactions in Helicobacter pylori infection. Gastroentero-logy 2008;134:306-23.

14. Suerbaum S, Michetti P. Helicobacter pylori infection. N Engl J Med 2002; 347:1175-86.

15. Syam AF, Miftahussurur M, Makmun D, et al. Risk factors and prevalence of Helicobacter pylori in five largest islands of Indonesia: a preliminary study. PLoS One 2015;10:e0140186

16. Santibáñez $M$, Aguirre $E$, Belda $S$, et al. Relationship between tobacco, cagA and vacA i1 virulence factors and bacterial load in patients infected by Helicobacter pylori. PLoS One. 2015; 10 : e0120444.

17. Ghosh P, Bodhankar SL. Association of smoking, alcohol and NSAIDs use with expression of cagA and cag T genes of Helicobacter pylori in salivary samples of asymptomatic subjects. Asian Pac J Trop Biomed. 2012;2:479-84. 
18. Said Essa A, Alaa Eldeen Nouh M, Mohammed Ghaniam N, et al. Prevalence of cagA in relation to clinical presentation of Helicobacter pylori infection in Egypt. Scand J Infect Dis 2008;40:730-3.

19. Kantarceken B, Aladag M, Atik E, et al. Association of CagA and VacA presence with ulcer and non-ulcer dyspepsia in a Turkish population. World J Gastroenterol 2003;9:1580-3.

20. Erzin $Y$, Koksal V, Altun $S$, et al. Prevalence of Helicobacter pylori vacA, cagA, cagE, iceA, babA2 genotypes and correlation with clinical outcome in Turkish patients with dyspepsia. Helicobacter 2006;11:574-80.
21. Parsonnet J, Friedman GD, Orentreich N, Vogelman H. Risk for gastric cancer in people with CagA positive or CagA negative Helicobacter pylori infection. Gut 1997;40:297-301.

22. Suriani R, Colozza M, Cardesi E, et al. CagA and VacA Helicobacter pylori antibodies in gastric can-cer. Can J Gastroenterol 2008;22:255-8.

23. Sozzi M, Valentini M, Figura $N$, et al. Atrophic gastritis and intestinal metaplasia in Helicobacter pylori infection: the role of CagA status. Am J Gastroenterol 1998;93:375-9. 